\title{
Adam Białkowski
}

Łódź

\author{
Sebastian Latocha \\ Uniwersytet Łódzki \\ Wydział Filozoficzno-Historyczny \\ Instytut Etnologii i Antropologii Kulturowej
}

\section{Muzeum w suszarni bielizny. O Izbie Pamięci Osiedla im. Józefa Montwilła-Mireckiego w Lodzi}

Prezentowany materiał składa się z dwóch części - 1) wstępu przedstawiającego Izbę Pamięci Osiedla im. Józefa Montwiłła-Mireckiego w Łodzi na tle podstawowych informacji o samym osiedlu, jego historii i społeczno-kulturowej specyfice tego miejsca będącej przedmiotem m.in. monografii autorstwa Doroty Fornalskiej i wielu artykułów prasowych ${ }^{1}$ oraz 2) roz-

\footnotetext{
${ }^{1}$ Ekologiczne, urbanistyczne, architektoniczne, historyczne, socjologiczne i etnograficzne aspekty egzystencji osiedla im. J. Montwiłła-Mireckiego są przedmiotem artykułów i reportaży prasowych, m.in.: Tutaj wszyscy mówią sobie „dzień dobry” Małgorzaty Szlachetki („Gazeta Wyborcza”, dodatek „Tygodnik Łódź”, 25 IX 2020 r., s. 10-11); Osiedle na Polesiu Konstantynowskim ma już 90 lat. To piękny jubileusz Anny Gronczewskiej („Dziennik Łódzki”, dodatek „Kocham Łódź”, 28 IX 2018 r., s. 8-9); Przedwojenne osiedla miały własne gazownie, kanalizację, wodociąg Anny Gronczewskiej („Dziennik Łódzki”, dodatek „Kocham Łódź”, 22 XI 2013 r., s. 8-9); Dzielnica bez tajemnic Joanny Rayzacher („Twoja Gazeta”, XII 2011 r., s. 20); Osiedle, które ma duszę Anny Gronczewskiej („Dziennik Łódzki”, 30 I 2009 r., s. 9); Jak u Pana Boga za piecem Mirosława Malinowskiego („Express Ilustrowany”, 20 X 2002 r., s. 16-17); Chmury w raju Agnieszki Ostapowicz („Dziennik Łódzki”, 27 VI 2000 r., s. 18). Same tytuły uchylają rąbka atmosfery sielskości, swojskości czy „miejsca antropologicznego” [Augé 2010] panującej - w oczach łódzkich dziennikarzy — na osiedlu. Z kolei monografia Doroty Fornalskiej pt. Osiedle Montwiłła-Mireckiego. Opowieść mieszkańców. Przed wojna - Wysiedlenia - Powroty [Fornalska 2018] eksponuje problem trudnego dziedzictwa tego miejsca.
} 
mowy Adama Białkowskiego z Tadeuszem Krzemińskim² na temat Izby Pamięci stanowiącej osiedlowe „muzeum”. Rozmowa odbyła się 17 stycznia 2020 r. w ramach projektu STACJA BADAWCZA - Osiedle im. J. Montwitła-Mireckiego $w$ Łodzi, który realizuje Instytut Etnologii i Antropologii Kulturowej Uniwersytetu Łódzkiego we współpracy z Radą Osiedla. Adam Białkowski prowadzi badania etnograficzne, na podstawie których pisze pracę licencjacką pt. Izba Pamięci Osiedla im. Józefa Montwiłła-Mireckiego $w$ Łodzi. Miejsce - ludzie - rzeczy (promotor: dr Sebastian Latocha).

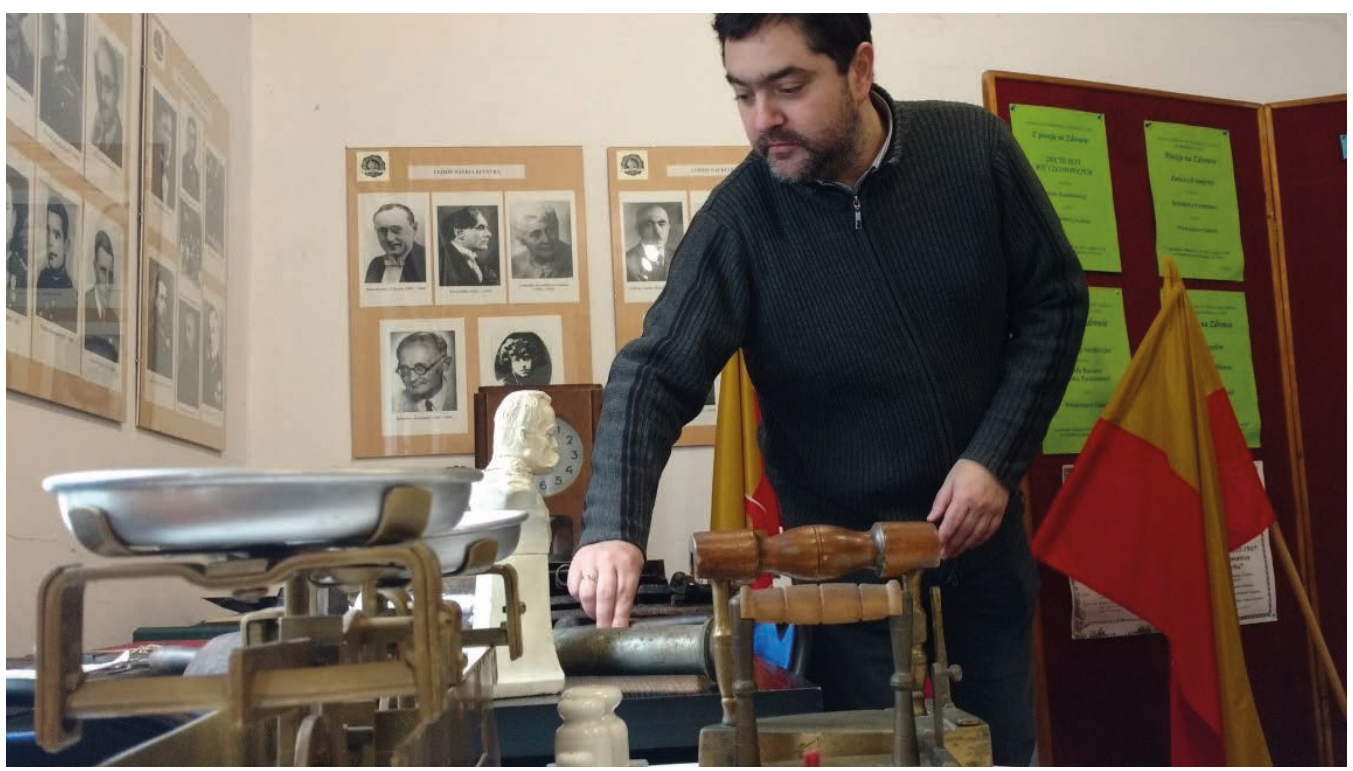

Il. 1. Prace inwentaryzacyjne w Izbie Pamięci prowadzone przez studentów łódzkiej etnologii pod kierunkiem dra Damiana Kasprzyka, styczeń 2020 r. (Fot. Sebastian Latocha)

\footnotetext{
${ }^{2}$ Tadeusz Krzemiński - urodził się w 1938 r., na osiedlu im. J. Montwiłła-Mireckiego w Łodzi mieszka od urodzenia (z przerwą w okresie II wojny światowej), do 2019 r. przewodniczący Rady Osiedla, prezes Stowarzyszenia Mieszkańców Osiedla im. J. Montwiłła-Mireckiego „Polesie”, współtwórca i opiekun Izby Pamięci, miłośnik, znawca i praktyk fotografii. Społecznik, skarbnica wiedzy o osiedlu, główny informator w trakcie badań etnograficznych Adama Białkowskiego na temat osiedlowego „muzeum”. T. Krzemiński jest, niestety, ostatnim żyjącym współtwórcą tego miejsca; jego pamięć jest podstawowym, bezcennym źródłem wiedzy o osiedlowej Izbie Pamięci, o jej historii i roli w krajobrazie kulturowym osiedla.
} 


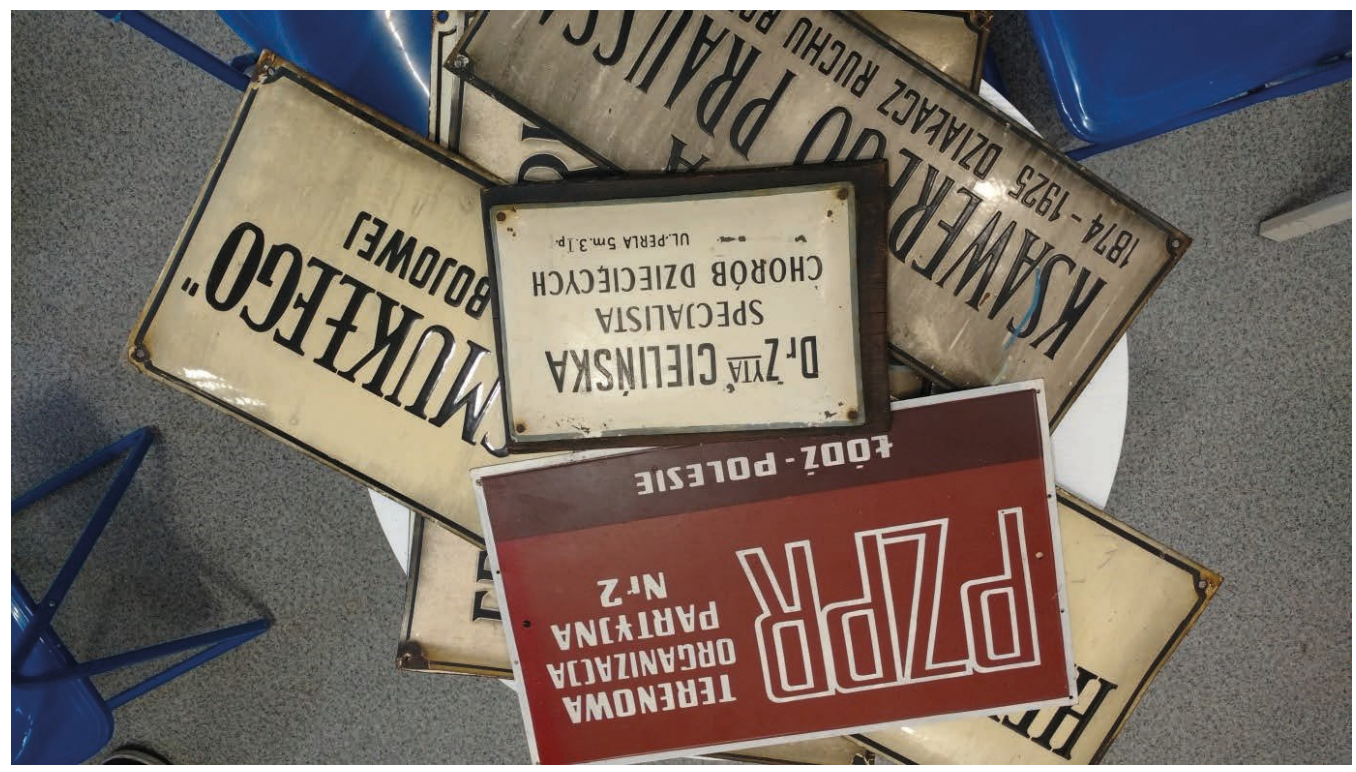

Il. 2. Stare szyldy i tablice z nazwami ulic pochodzące z przestrzeni publicznej osiedla, będące przedmiotem inwentaryzacji Izby Pamięci, jaka miała miejsce w styczniu $2020 \mathrm{r}$. (Fot. Sebastian Latocha)

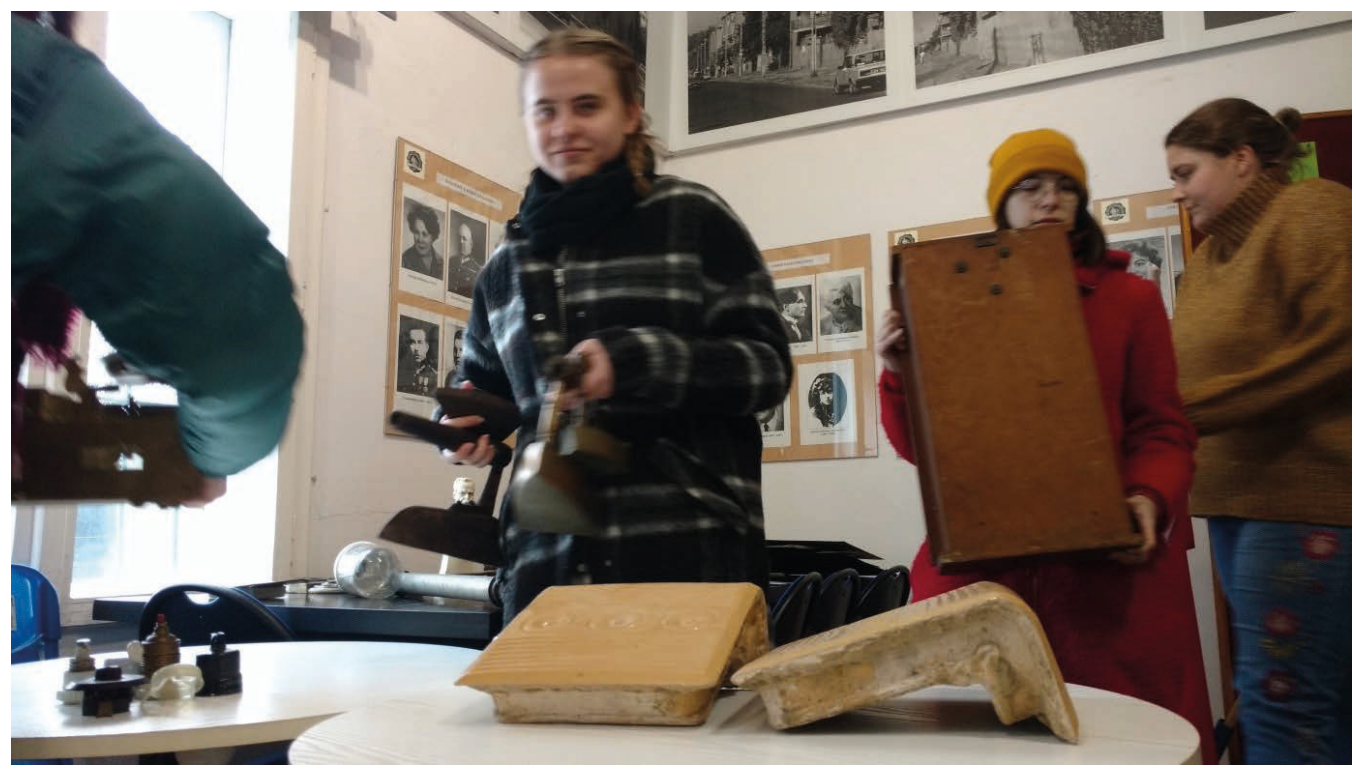

Il. 3. Studenci łódzkiej etnologii podczas inwentaryzacji osiedlowego „muzeum” w suszarni bielizny, styczeń 2020 r. (Fot. Sebastian Latocha) 
Przedwojenne modernistyczne osiedle im. Józefa Montwiłła-Mireckiego jest jednym z 36 jednostek administracyjnych Łodzi. W skali całego miasta to naprawdę małe osiedle, które można obejść dosłownie w kwadrans z zegarkiem w ręku. Leży w północno-zachodniej części miasta, w trójkącie ulic Srebrzyńskiej, Jarzynowej i al. Unii Lubelskiej. Ani w centrum, ani na peryferiach; spokojne, kameralne osiedle wyróżnia się jednak urbanistycznie i architektonicznie w lokalnym krajobrazie miejskim. Ma bardzo wyraźne granice przestrzenne. Jego wschodnią granicą jest zielony pas ogródków działkowych i linia kolejowa, od południa osiedle graniczy z parkiem im. Józefa Piłsudskiego, a podziemna rzeka Łódka okala je od zachodu i północy.

Osiedle powstało w latach 1928-1933 według realizującego modne hasła awangardy i modernizmu projektu Jerzego Berlinera, Jana Łukasika, Miruty Słońskiej i Witolda Szereszewskiego. Było pierwszym łódzkim blokowiskiem, jednym z pierwszych w Polsce i Europie. Choć projekt składał się z 33 bloków [Olenderek 2012: 36], w dobie kryzysu ekonomicznego w latach 30. XX w. powstało ich w sumie 21. Dzisiaj osiedle jest perłą łódzkiej architektury i urbanistyki nowoczesnej. Kubiczne bryły bloków o płaskich dachach urozmaicają ryzality, balkony i charakterystyczne międzyokienne słupki z „gołej” czerwonej cegły [Ciarkowski, Stefański 2018: 70]. Mieszkania - jak na przedwojenne łódzkie warunki - miały wysoki standard (gaz, elektryczność, WC, duże okna, balkony). Osiedle miało być dla robotników, jednak „zamiast nich — przypomnijmy o kryzysie — wprowadziła się łódzka elita: policjanci, urzędnicy oraz artyści” [Rayzacher 2011: 20]. Z modernistycznym osiedlem zrosły się biografie artystów z kręgu awangardy: Karola Hillera, Katarzyny Kobro i Władysława Strzemińskiego oraz Mariana Minicha, dyrektora dzisiejszego Muzeum Sztuki w Łodzi.

Nie od dziś wiemy, że miejsca miewają rys palimpsestu³, którego kolejne warstwy albo harmonizują ze sobą, albo wchodzą w konflikt ${ }^{4}$. Dotyczy to

\footnotetext{
${ }^{3}$ Anna Zalewska definiuje palimpsest jako „proces nakładania się kolejnych działań, których pozostałości zostają w jego toku tylko częściowo zatarte bądź zmienione” [Zalewska 2014: 318]. Tę definicję przyjmujemy w niniejszym artykule.

${ }^{4}$ Przykładem konfliktu różnych pamięci czy tożsamości miejsca jest trudne dziedzictwo (ang. dissonant heritage, difficult heritage). Otwiera ono podziały społeczne [Macdonald 2001: 1], jest przestrzenią niezgody w sprawie przeszłości [Dragićević-Šešić, Rogač-Mojatović 2014: 11]. Niechciana przeszłość przekształca się w niechciane miejsce, a jeśli jego wyjątkowość podkreśla się, opierając się właśnie na trudnym dziedzictwie, negatywne kono-
} 
przede wszystkim miejsc, w których liczebnik „wiele” odnosi się do kategorii kulturowych, takich jak opowieść, pamięć, tożsamość, dziedzictwo, tradycja. Osiedle Mireckiego według nas jest właśnie takim miejscem-palimpsestem, którego dwiema najbardziej rzucającymi się w oczy warstwami są „tożsamość modernistyczna” i „tożsamość martyrologiczna”. Tragiczna biografia Karola Hillera [Gronczewska 2011: 7] pokazuje, że obie składają się na wspólne dziedzictwo tego miejsca. „Tożsamość modernistyczna” przyciąga na osiedle nowych mieszkańców, „tożsamość martyrologiczną” pielęgnują raczej tzw. starzy mieszkańcy, których rodzinne biografie zrosły się z osiedlem i korzeniami sięgają przedwojnia [zob. Latocha 2020].

Nasz artykuł koncentruje się przede wszystkim na tej części dziedzictwa osiedla Mireckiego, o którą troszczą się lokalni animatorzy, która stanowi ekspozycję osiedlowego „muzeum”, czyli Izby Pamięci.

Sam fakt, że miejsce to w ogóle egzystuje na mapie łódzkich instytucji kultury ${ }^{5}$, według nas, jest manifestacją silnej lokalnej „tożsamości martyrologicznej”. W czasie II wojny światowej osiedle Mireckiego było miejscem prześladowania i wysiedlenia ponad 4 tys. mieszkańców. Z 14 na 15 stycznia 1940 r. rozpoczął się koszmar ${ }^{6}$, który Dorota Fornalska określa „nocą, która zmieniła wszystko” [Fornalska 2018: 97-110]. Po wojnie część mieszkańców wróciła na osiedle. Wśród tych żyjących dzisiaj „na Montwille” — jak mówią mieszkańcy - są osoby pamiętające tę noc i spadkobiercy trudnej pamięci - ich dzieci i wnuki. Mieszkańcy pielęgnują to martyrologiczne dziedzictwo:

- w czasie - podczas uroczystych rocznic styczniowej tragedii (mających kształt lokalnego świeckiego „święta”),

tacje zawłaszczają wyróżnienie [Battilani, Bernini, Mariotti 2018: 1420]. Tragiczna historia osiedla (wysiedlenie mieszkańców podczas II wojny światowej) i wynikająca z niej jego współczesna „martyrologiczna tożsamość” nie mają jednak wszystkich cech trudnego dziedzictwa. Pamięć (o wysiedleniu mieszkańców, o Niemcach bałtyckich, których żyli na osiedlu w czasie wojny) nie otwiera wyraźnie podziałów społecznych, nie wchodzi w otwarty konflikt z „tożsamością awangardową”.

${ }^{5}$ Chodzi nam o sens potoczny tego pojęcia, nie o podmiot, którego działalność określa Ustawa z 25 października 1991 r. o organizowaniu i prowadzeniu działalności kulturalnej.

${ }^{6}$ „Ranek 15 stycznia 1940 roku zastał Osiedle opustoszałe, zastygłe w strachu nocy. Gdzieniegdzie błąkały się bezpańskie już psy. Jak czuli się ci, którzy zostali? Może towarzyszyło im uczucie ulgi, że to nie oni tym razem, a może lęku, że ich kolej też nadejdzie. Z pewnością obawiali się o los swoich znajomych, tak niedawno jeszcze razem rozmawiali, grali w brydża, wymieniali się politycznymi nowinkami, wspólnie prowadzili dzieci do szkoły i przedszkola. Wielu z nich już w pierwszych dniach będzie starało się pomóc sąsiadom, dostarczając do obozu żywność oraz ciepłe ubrania, kołdry i poduszki” [Fornalska 2018: 110]. 
— oraz w przestrzeni - gromadząc i eksponując w Izbie Pamięci (osiedlowej „świętej” przestrzeni) dokumenty, pamiątki i inne artefakty, które mają związek z nie zawsze „łatwą” przeszłością w wymiarze lokalnym. Miejsce to i przedmioty składające się na ekspozycję są głównym tematem naszego artykułu i rozmowy z Tadeuszem Krzemińskim.

„Muzeum” mieści się w drewnianym „zielonym baraku” (tak mieszkańcy osiedla z czułością nazywają to miejsce) po przedwojennej suszarni bielizny przy ul. Perla 2, w sąsiedztwie starej gazowni. Jest reliktem osiedlowej zabytkowej infrastruktury publicznej; w krajobrazie osiedla zachował się tylko jeden taki barak, których pierwotnie było kilka. Parterowy drewniak dzisiaj jest siedzibą kilku instytucji: Rady Osiedla, Punktu Pracy Socjalnej Miejskiego Ośrodka Pomocy Społecznej w Łodzi i Stowarzyszenia Mieszkańców Osiedla im. J. Montwiłła-Mireckiego „Polesie” troszczącego się o Izbę Pamięci, która powstała w 1987 r. „Zanim do tego doszło, społecznicy i historycy (jak pan Eligiusz Błaszczyk) gromadzili przez szereg lat, selekcjonowali i opisywali eksponaty” [Gicgier 1993: 13]. W 2000 r. miał miejsce remont, który nadał temu „muzeum” jego dzisiejszy kształt. Skromna (jeśli chodzi o ilość muzealiów) kolekcja składa się z takich eksponatów, jak zabytkowy bojler, przedwojenna pralka Miele, stara wyżymaczka, tary do prania, żelazka z duszą, stary zegar, waga kuchenna, drewniana stolnica, prawidła do butów i inne przedmioty codziennego, prozaicznego zastosowania. Wzbogacają ją stare szyldy i tablice z nazwami ulic na beżowym tle oraz dokumenty ważne z perspektywy historii osiedla, segregatory z sylwetkami mieszkańców „Montwiłła”: więźniów obozów i żołnierzy II wojny światowej, rewolucjonistów, działaczy PPS, pracowników samorządowych, ludzi nauki i kultury, w końcu — samych założycieli Izby Pamięci. Ciekawym eksponatem jest makieta osiedla. Na ścianach — galeria postaci z Józefem Montwiłłem-Mireckim na czele. W szklanych gablotach — kilkanaście egzemplarzy biuletynu „Polesie” oraz kilka książek o tematyce martyrologicznej, wojennej. Lecz w koncepcji tego miejsca nie o rzeczy chodzi tak naprawdę, ale o ideę. Izba Pamięci jest przestrzenią kolekcjonującą, skupiającą i pielęgnującą to, co José van Dijk określa jako zmediatyzowaną pamięć. „Przedmioty te zapośredniczają przywołanie nie tylko minionych rzeczy, ale także relacji między jednostkami i różnego rodzaju grupami” [van Dijck 2018: 127]. W tym sensie Izba Pamięci ma walor integracyjny 
w skali osiedla. Społecznicy wspólnie troszczą się o tę zmediatyzowaną pamięć będącą częścią ich autobiograficznej i kulturowej tożsamości.

Mały „zielony barak” wygląda kuriozalnie na tle masywnych, kanciastych szarych bloków. Wejście do Izby Pamięci znajduje się z boku, w szczycie budynku, na wprost klatki schodowej bloku przy ul. Srebrzyńskiej 81. Gigantyczny skobel w drzwiach nie zaprasza do środka. Bardziej chroni dziedzictwo, niż je eksponuje, zamykając w dwóch pokojach eksponaty egzystujące niejako „dla siebie”. Poza ciszą i półmrokiem nikt ich nie pilnuje. „Muzeum” w suszarni bielizny nie jest miejską instytucją kultury, nie ma jej na mapie łódzkich muzeów, nie jest miejscem pracy kustosza muzealnego. Społeczni opiekunowie niby-muzeum otwierają je z konkretnych powodów, przy okazji osiedlowych „świąt” czy zebrań Rady Osiedla. Ma miejsce „rytuał” przekazania kluczy, zdjęcia skobla, odsłonięcia rolet. Pośród samotnych na co dzień i zakurzonych przedmiotów odbywają się „ryty” o charakterze obywatelskim i wspólnotowym.

Trwa inwentaryzacja ${ }^{7}$ wystawy stałej Izby Pamięci, co pozornie wydaje się przedsięwzięciem banalnym. Jednak biorąc pod uwagę fakt, że jest to pierwsza tego typu próba (katalog), rysem tego pomysłu, obok prostoty, jest również realizacja celu antropologii „naglącej”-wyczulonej na przemijalność świata. Stowarzyszenie Mieszkańców Osiedla im. J. Montwiłła-Mireckiego „Polesie”, które dba o Izbę Pamięci, wytraciło swoją energię, a jak stwierdza w rozmowie Tadeusz Krzemiński, nie za bardzo jest komu przekazać pałeczkę. Warunki panujące w „zielonym baraku” (niska temperatura zimą, brak ogrzewania, wilgoć) nie sprzyjają rzeczom, jakie znajdują się w Izbie Pamięci. Co więcej, na początku ekspozycja powiększała się niejako sama, siłą rozpędu - w konsekwencji spontanicznych gestów mieszkańców, którzy wzbogacali Izbę Pamięci o przedmioty, które „odkrywali” w swoich piwnicach. Artefaktów nikt nie liczył, nikt ich nie opisywał — stąd pilna potrzeba dokumentacji, którą realizuje katalog. Dzisiaj mieszkańcy nie przynoszą eksponatów, wystawa nie rozwija się, jest stała (jeśli nawet nie martwa). Mieszkańcy osiedla Mireckiego mogliby przynieść do „muzeum” w suszarni bielizny cenne artefakty będące częścią trudnego dziedzictwa tego miejsca (np. porcelanowe talerze ze swastyką, których Niemcy nie zabrali ze sobą, uciekając stąd pod koniec II wojny światowej). Dlaczego tego nie robią? Nawet Tadeusz Krzemiński dla ślubnych obrączek swoich rodziców znalazł inne miejsce...

${ }^{7}$ Inwentaryzacja jest częścią koncepcji pracy licencjackiej Adama Białkowskiego. 
Rozmowa ${ }^{8} \mathrm{z}$ Tadeuszem Krzemińskim, lokalnym ekspertem w kwestii Izby Pamięci, posiada walor antropologii „naglącej”, która bada m.in. kulturę pamięciową, rekonstruując przeszłość na podstawie pamięci ostatnich świadków [Posern-Zieliński 1987: 34-35]. Postulat ten wynika z „naglącej potrzeby skoncentrowania się przede wszystkim na nich, zanim nie będzie za późno na dobycie jakichkolwiek informacji” [Posern-Zieliński 1987: 35].

\section{Część II — rozmowa w mieszkaniu Tadeusza Krzemińskiego}

\section{ADAM BIAŁKOWSKI: Mieszka pan na osiedlu od urodzenia?}

TADEUSZ KRZEMIŃSKI: Tak i to cały czas w tym samym mieszkaniu z przerwą na okres okupacji. 14 stycznia 1940 r. zostaliśmy stąd wyrzuceni, mama, ja i moja siostra. Ojca już nie było. Został aresztowany 9 listopada 1939 r. Przez siedemdziesiąt lat nie wiedzieliśmy w ogóle, co się z ojcem stało, ale to jest inna ważna dla mnie historia, ale nie o Izbie Pamięci, o której mieliśmy rozmawiać.

AB: Izba Pamięci jest miejscem, gdzie kultywuje się pamięć, więc historia pana rodziny i historia Izby są ze sobą połączone. Jakie były okoliczności powstania Izby?

TK: W historii tego miejsca są dwa etapy. Najpierw została zorganizowana Izba w takim prymitywnym wydaniu, później zaczęła podupadać. Problemy finansowe, mała aktywność. Później przychodziła młodzież i grając w ping-ponga, zniszczyła ją, w końcu została zamknięta. Ale ją wskrzesiliśmy. Miałem w tym swój bezpośredni udział. Urząd Miasta Łodzi z powrotem przekazał nam klucze. Z administracji przeprowadziliśmy remont za własne pieniądze nawet, odnowiliśmy ekspozycję i to jest ten drugi etap życia Izby. Jeśli zaś chodzi o ten pierwszy etap, to ja znam szczegóły, ponieważ do mnie się zwrócił pan Pietrzyk, ojciec Jarosława Pietrzyka9 prezydenta miasta. Ojciec pana prezydenta, bardzo solidny, porządny człowiek, prawnik, mieszkał na naszym osiedlu i chciał jakoś podnieść rangę tego miejsca. Wspólnie z takim małżeństwem, zresztą zawsze z nazwiskami miałem problem, założyli tę Izbę. Pan Pietrzyk poprosił mnie, żebym zrobił trochę reprodukcji zdjęć różnych osób, które mieszkały na

${ }^{8} \mathrm{Nie}$ jest to surowa transkrypcja rozmowy, a jej postać informacyjna (liczne skróty, korekty).

${ }^{9}$ Jarosław Kazimierz Pietrzyk — prezydent miasta Łodzi w latach 1985-1989. 
osiedlu. Zrobiłem. Oni powiesili je na ścianie, zaprosili prezydenta, żeby zobaczył, że jest Izba Pamięci. Taki był początek.

AB: I pan ma swój udział w tym początku...

TK: Raczej tak „z boku”, nie włączając się za bardzo w ten pierwszy etap. Tylko że pan Pietrzyk wiedział, że ja się pasjonuję fotografią, więc zwrócił się do mnie o pomoc przy tej galerii.

\section{AB: Kto w takim razie założył Izbę, oprócz pana Pietrzyka?}

TK: Izbę założyły trzy osoby, pan Franciszek Pietrzyk i, przypomniałem sobie, pan Tadeusz Boniecki z żoną i pan Eligiusz Błaszczyk. Oni tak naprawdę założyli to miejsce. Wszyscy, niestety, nie żyją.

AB: Na szczęście mam okazję z panem porozmawiać. Nikt inny nie przedstawi okoliczności powstania Izby tak jak pan, ponieważ pan był najbliżej tych ludzi, którym zawdzięczamy to miejsce.

TK: To prawda, chociaż nie założyłem Izby, to ją wywalczyłem po tym okresie zamknięcia. Odzyskanie Izby miało miejsce w dniu 8 czerwca 2006 r. Po trwających pół roku działaniach i negocjacjach podpisaliśmy w Urzędzie Miasta Łodzi umowę użyczenia lokalu dla stowarzyszenia bez opłat, bo mieliśmy Izbę do własnej dyspozycji, ale mieliśmy ponad $200 \mathrm{zł}$ czynszu. Teraz mamy tylko symboliczne 5 zł, ale była ostra walka. Założyłem Stowarzyszenie Mieszkańców Osiedla im. J. Montwiłła-Mireckiego „Polesie”. To była moja inicjatywa. A klucze to dostaliśmy w połowie 2005 r. z administracji po rezygnacji prezesa stowarzyszenia, który powiedział: „Panie Tadeuszu, co pan zrobił? Dwieście złotych mamy płacić czynszu, a my nie mamy pieniędzy”, a ja zaryzykowałem i wyszło dobrze. Klucze mieliśmy, ale groziło zamknięcie Izby, bo zalegaliśmy z czynszem. Na szczęście miasto umorzyło zaległości. Trzydzieści lat byłem w Radzie Osiedla, nawet jej przewodniczyłem, ale z tymi miejskimi organami osiedlowymi jest tak, że są takie płynne, raz są, miasto niby ich potrzebuje, ale działają tak, jakby ich nie było. Jeszcze będąc w Radzie Osiedla, wpadłem na pomysł, żeby stworzyć stowarzyszenie, które będzie nasze, ale przydałby nam się jakiś lokal. I żeby utrzymać te Izbę, powołaliśmy do życia stowarzyszenie. I to się wszystko ze sobą łączy, ponieważ w tym miejscu działa i Rada Osiedla, i nasze stowarzyszenie, no i Izba Pamięci. Stowarzyszenie działa tak, że organizuje różne spotkania, na które zaprasza mieszkańców. Jakieś prezentacje, ściągamy tutaj podróżników, ludzi, którzy mają prelekcje z dziedziny historii, a w międzyczasie przychodzi młodzież ze szkoły pooglądać i posłuchać trochę tej historii. Przychodzą i wycieczki, które interesują 
się naszym osiedlem. Goszczeni są w Izbie Pamięci, częstujemy gorącymi napojami. Oglądają to, co jest. W tej chwili jest nowa Rada Osiedla, dałem młodzieży możliwość działania w Izbie i oni bardzo intensywnie pracują, do tego stopnia, że ja muszę się o klucze prosić. Nie podoba mi się trochę, że młodzi inaczej podchodzą do eksponatów. Kiedyś to była prawdziwa, elegancka ekspozycja muzealna, a nie magazynek. Ale to szybko można naprawić.

AB: To stary, zabytkowy drewniany budynek, który nie powstał jako siedziba dla instytucji kultury, tym bardziej dla muzeum. Jak w związku z tym się pracuje i eksponuje muzealia w suszarni bielizny?

TK: Izba Pamięci zimą nie działa, ponieważ nie ma centralnego ogrzewania. Jest piec węglowy. Dzień albo dwa przed spotkaniem palę w nim, żeby było 15-16 stopni, więc i tak siedzimy w kurtkach.

AB: Czy dobrze rozumiem, że Izba, chociaż jest takim minimuzeum, to realizuje głównie cele integracyjne?

TK: Bardzo dobrze pan to rozumie. Izba to nam służy jako takie spoidło, proszę pana, do integracji. Jako mieszkańcy założyliśmy stowarzyszenie, żeby mieć pieczątkę, która wiele załatwia w mieście. Izba jest bardzo ważna, ale jej działalność muzealna jest, niestety, słaba. Dlaczego? Bo nie ma kustosza, który mógłby się nią merytorycznie zająć, dbałby o ekspozycję. Ja bym chciał, żeby Izba się rozwinęła, ale sam już nie daję rady, powoli się wycofuję. W moim wieku chciałbym mieć czas dla siebie i dla fotografii.

AB: Jak wyobraża sobie pan to miejsce za pięć lat?

TK: Właśnie szukam kogoś, kto wziąłby odpowiedzialność za Izbę, za eksponaty. Chciałbym, żeby ktoś to po mnie przejął, bo ja poświęciłem temu miejscu bardzo dużo czasu. Mam segregator z wycinkami z łódzkich gazet, z artykułami o naszym osiedlu w układzie chronologicznym. Chciałbym go przekazać komuś, kto po prostu tego nie wyrzuci na śmietnik. Drugi segregator dotyczy ofiar na Brusie ${ }^{10}$, gdzie między innymi zostały znalezione szczątki mojego ojca dzięki obrączce. Artykuły w prasie mówiły o połączeniu się dwóch obrączek, bo ja miałem mamy obrączkę. Siedemdziesiąt lat one nie miały jakby, metafizycznie rzecz biorąc, kontaktu ze sobą. Mam biuletyny osiedlowe. To wszystko trzeba opracować i umieścić w Izbie, gdzie są książki poświęcone historii osiedla i kopie dokumentów $\mathrm{z}$ archiwum. Koleżanki cały tydzień siedziały w archiwum i je kserowały.

\footnotetext{
${ }^{10}$ Brus to dzielnica Łodzi leżąca w zachodniej części miasta. Znajduje się w niej stary poligon wojskowy - miejsce pochówku ofiar totalitaryzmów: nazizmu i komunizmu.
} 
Są również biogramy mieszkańców, czyli nie tyle rzeczy, ile dokumenty przede wszystkim. Myślę, że to one stanowią o wartości Izby. Jak ja sobie wyobrażam to miejsce za pięć lat? Niech ktoś weźmie to wszystko, zadba, poukłada i zajmie się zbieraniem rzeczy, które są po piwnicach, ogłosi zbiórkę i tak rozwinie Izbę.

\section{AB: I nikt nie chce tego przejąć?}

TK: Wie pan, to się zbliża, ja mam osiemdziesiąt dwa lata, więc nie pociągnę za długo, niestety. I chciałbym, żeby ktoś to wziął, ktoś odpowiedzialny, ale czy tak się stanie? Nie wiem. Miasto cały czas kontroluje Izbę. Jeśli urzędnicy zobaczą, że to jest magazynek, a nie ekspozycja muzealna, to się skończy. A więc boję się o przyszłość tego miejsca. Proszę pana, Izba została powierzona mnie. Historia mojej rodziny jest częścią historii osiedla i dlatego nie chciałbym, żeby coś złego stało się z Izbą.

\section{Część II — kontynuacja rozmowy w Izbie Pamięci Osiedla im. J. Montwiłła-Mireckiego w Lodzi}

TK: Tak to wygląda, są dwa pokoje i zaplecze. Jesteśmy w sali ogólnej, gdzie nie ma eksponatów, jest tylko ścienna galeria postaci i reprodukcje archiwalnych zdjęć z osiedla i obozu przy ulicy Łąkowej z okresu II wojny światowej, gdzie w styczniu 1940 r. znaleźliśmy się po wysiedleniu z naszych mieszkań. Tutaj się spotykamy, są stoły, krzesła. W drugim etapie życia Izby tak to urządziliśmy. To jest najważniejsza część Izby, bo to jest pamięć. Dlatego Izba Pamięci to jest właśnie tutaj, a w drugim pokoju jest takie małe muzeum...

\section{AB: A co znajduje się w tym minimuzeum?}

TK: Mamy przedmioty, których używaliśmy na co dzień na samym początku naszego życia na osiedlu. Tak wyglądała łazienka. Tutaj piec łazienkowy, który ściągnęliśmy z piwnicy. Wanny były w mieszkaniach, ale tutaj się paliło w piecu, musieliśmy węgiel stale dorzucać, no i jak się woda nagrzała, to leciała przez prysznic. Jest i węglareczka od mojej babci. Urządzenia stolarskie, narzędzia. Ja tego miałem sporo, bo u mnie stolarz w czasach okupacji mieszkał, więc tam było sporo po nim rzeczy. Różnego typu plakaty. Wielu rzeczy nie ma w ekspozycji, są na zapleczu, głównie dokumenty. A to jest makieta osiedla autorstwa Jerzego Miki. Jest sporo rzeczy, na przykład takie wyżymaczki, których dzisiaj nie ma w zastosowaniu, a to są nasze po prostu sprzęty, z którymi żyliśmy. Na tej tarce, pamiętam, moja mama prała. 


\section{AB: Jest katalog tych eksponatów?}

TK: Nie ma. Katalog to byłoby naprawdę coś!

AB: Chciałby pan, żeby to miejsce stało się prawdziwym muzeum?

TK: Tak! Magazynek to nie jest dobry kierunek rozwoju.

AB: Jak rzeczy trafiają tutaj?

TK: Jedne przynoszą sami mieszkańcy, drugie przynosimy my z piwnic $\mathrm{z}$ całego osiedla.

\section{AB: Ten bojler?}

TK: Pomalowaliśmy go, bo on był taki zardzewiały. Wyczyściliśmy go i postawiliśmy tutaj. Stał w piwnicy i się marnował, a teraz ludzie przychodzą i zachwycają się nim. Każdy ma dodatkową własną historię na temat przedmiotów. Między innymi ja wspominam, jak moja mama się pyta: „No to co? Jutro robimy kąpiel? Dobra, no to przynieś więcej węgla!” Poleciałem po węgiel do piwnicy, przyniosłem właśnie w kubełeczku. Stał ten węgiel, dobra, napaliłem, no i siedzieliśmy w pokoju, graliśmy w warcaby albo czytaliśmy. Mama krzyczy: „Idź, zobacz, czy już gotowa kąpiel jest!” No to ja poszedłem do łazienki i tak...[Tadeusz Krzemiński, przykładając dłoń do bojlera, demonstruje, jak sprawdzało się, czy woda się nagrzała.] Jak dojechało do tego miejsca, to krzyknąłem: „Mama! Jedna kąpiel już jest!” Mama na to: „No to ty się kąpiesz pierwszy.” No to ja leciałem się kąpać. W międzyczasie, jak dojechało dalej, mama kazała spuścić wodę i kąpała się Hania, a ona po Hani. Ale z jednego kotła były dwie kąpiele. Tak to wyglądało. Pamiętam, jak leciałem do łazienki i sprawdzałem ten bojler, czy woda się nagrzała.

\section{AB: Może by tak ożywić eksponaty takimi historiami jak ta?}

TK: Może tak, ale nie było głowy, żeby to zrobić. Jest bojler i tyle. A to cały wieczór był poświęcony kąpieli. Uciecha niesamowita. Napuszczało się wody do wanny, bardzo delikatnie, żeby nie za dużo, żeby oszczędnie było. I te kureczki! Wajchę się przesuwało, gałeczki, C jak ciepła, Z jak zimna. A to z kolei jest przedmiot, który znalazłem na ulicy, to taka tablica geodety jest. A to, niby nic, szyld, ale przez długie lata u nas mieszkała pani doktor Cielińska i ona miała pod opieką wszystkie dzieci z osiedla.

AB: Znała wszystkie dzieci na osiedlu?

TK: No tak! Ona wychodziła i pytała: „No i jak się czujesz?”, „A tobie przeszło?” U nas wszyscy się znali. W Urzędzie Miasta Łodzi była opinia, że u nas to jak miasto w mieście. Mam nadzieję, że młodzi przejmą to dziedzictwo z odpowiedzialnością. Jest nowa Rada Osiedla, ludzie właśnie 
młodzi, inteligentni. Osiedle jest dla nich priorytetem. Liczę na nich i życzę, żeby nie zrobili z Izby magazynku.

\section{Bibliografia}

\section{Augé Marc}

2010: Nie-miejsca. Wprowadzenie do antropologii hipernowoczesności, tłum. R. Chymkowski, Warszawa: Wydawnictwo Naukowe PWN.

\section{Battilani Patrizia, Bernini Cristina, Mariotti Alessia}

2018: How to cope with dissonant heritage: a way towards sustainable tourism development, „Journal of Sustainable Tourism”, vol. 26, no. 8.

\section{Ciarkowski Błażej, Stefański Krzysztof}

2018: Modernizm w architekturze Łodzi XX wieku, Łódź: Dom Wydawniczy Księży Młyn. van Dijck José

2018: Pamięć zmediatyzowana jako narzędzie pojęciowe, tłum. R. Chymkowski, [w:] Antropologia pamięci. Zagadnienia i wybór tekstów, P. Majewski, M. Napiórkowski (red.), Warszawa: Wydawnictwo Uniwersytetu Warszawskiego.

\section{Dragićević-Šešić Milena, Rogač-Mojatović Ljiljana}

2014: Balkan Dissonant Heritage Narratives (and Their Attractiveness) for Tourism, „American Journal of Tourism Management”, 3 (1b).

\section{Fornalska Dorota}

2018: Osiedle Montwiłła-Mireckiego. Opowieść mieszkańców. Przed wojną / wysiedlenia / powroty, Łódź: Dom Wydawniczy Księży Młyn.

\section{Gicgier Tadeusz}

1993: Polesie Konstantynowskie, „Dziennik Łódzki”, 19-20 czerwca.

\section{Gronczewska Anna}

2018: Osiedle na Polesiu Konstantynowskim ma już 90 lat. To piękny jubileusz, „Kocham Łódź” (dodatek do „Dziennika Łódzkiego”), 28 września.

2013: Przedwojenne osiedla miały własne gazownie, kanalizacje, wodociag, „Kocham Łódź” (dodatek do „Polska. Dziennik Łódzki”), 22 listopada.

2011: Tragiczny los Karola Hillera i jego dziet, „Kocham Łódź” (dodatek do „Polska. Dziennik Łódzki”), 7 stycznia.

2009: Osiedle, które ma duszę, „Dziennik Łódzki”, 30 stycznia.

\section{Latocha Sebastian}

2020: Animation of a Local Urban Community. Sebastian Latocha Talks to Remigiusz Kaczmarek, the Chairman of the Józef Montwiłt-Mirecki Community Council in Łódź, „Łódzkie Studia Etnograficzne”, t. 59.

\section{Macdonald Sharon}

2009: Difficult heritage. Negotiating the Nazi past in Nuremberg and beyond, LondonNew York: Routledge.

\section{Malinowski Mirosław}

2002: Jak u Pana Boga za piecem Mirosława Malinowskiego, „Express Ilustrowany”, 20 października. 


\section{Olenderek Joanna}

2012: Łódzki modernizm i inne nurty przedwojennego budownictwa, t. 2, Łódź: Dom Wydawniczy Księży Młyn.

\section{Ostapowicz Agnieszka}

2000: Chmury w raju, „Dziennik Łódzki”, 27 czerwca.

\section{Posern-Zieliński Aleksander}

1987: Antropologia „naglaca”, [w:] Słownik etnologiczny. Terminy ogólne, Z. Staszczak (red.), Warszawa - Poznań: Państwowe Wydawnictwo Naukowe.

\section{Rayzacher Joanna}

2011: Dzielnica petna tajemnic, „Twoja Gazeta”, grudzień.

\section{Szlachetka Małgorzata}

2020: Tutaj wszyscy mówią sobie „dzień dobry”, „Tygodnik Łódź” (dodatek do „Gazety Wyborczej”), 25 września.

\section{Zalewska Anna}

2014: Palimpsest, [w:] Modi memorandi. Leksykon kultury pamięci, M. Saryusz-Wolska, R. Traba (red.), Warszawa: Wydawnictwo Naukowe Scholar.

\section{Adam Białkowski \\ Sebastian Latocha \\ Musem in a Linen Drying Room. About the Józef Montwiłl-Mirecki Memorial Chamber in Łódź}

The article is devoted to the mini museum housed in the historic "green barrack," a converted linen drying room, situated in the modernist Józef Montwiłł- Mirecki dictrict in Łódź built in the interwar period. The Memorial Chamber - this is the name of the institution does not exist on the map of municipal cultural institutions. It operates on the outskirts of urban cultural life, but is a symbolic center of the district, materializes the "mediated memory" (van Dijk) and the autobiographical and cultural identity of the local community. The conversation with Tadeusz Krzemiński, one of the last living creators of the Chamber, is about the beginning of the Memorial Chamber, about the people integrating in it, about the museum exhibits and about the mundane problems of existence in this place.

Key words: museum, mediated memory, Józef Montwiłł-Mirecki District in Łódź, local community 